\title{
Egg Production, Fertility, Hatchability and Luteinizing Hormone Profile of Progesterone Hormone Injected to Arabic Gold Chicken (Gallus turcicus)
}

\author{
Iswati $^{1,2}$, Muhammad H. Natsir ${ }^{3}$, Gatot Ciptadi $^{3}$, and Trinil Susilawati ${ }^{3}$ * \\ ${ }^{1}$ Reproduction Laboratory of Agricultural Development Polytechnic Malang, 65141, Indonesia \\ ${ }^{2}$ Doctoral student, Faculty of Animal Science, Brawijaya University, Malang, 65145, Indonesia \\ ${ }^{3}$ Faculty of Animal Science, Brawijaya University, Malang, 65145, Indonesia \\ *Corresponding author's Email: tsusilawati@ub.ac.id; ORCID: 0000-0001-8535-151X
}

Received: 06 Jan. 2021

Accepted: 22 Feb. 2021

\begin{abstract}
The production and reproduction performance of chicken depends on their hormonal status, especially progesterone hormone, which has been known to correlate with egg production. The present study aimed to analyze the effect of progesterone hormone injection on Arabic Gold chickens (Gallus turcicus) regarding egg production and luteinizing hormone concentration in blood plasma. A total number of 60 Arabic Gold chickens aged 26-weeks were divided into three groups based on injected hormone concentration $\left(\mathrm{P}_{0}\right.$ : control; $\mathrm{P}_{1}: 1 \mathrm{mg} /$ chicken; $\left.\mathrm{P}_{2}: 2 \mathrm{mg} / \mathrm{chicken}\right)$. The study was conducted using a completely randomized design and the obtained data were analyzed with a descriptive analysis for qualitative data and one-way analysis of variance followed with Duncan's Multiple Range Test as a post hoc test for the quantitative data. The results presented that progesterone hormone injection had a significant effect on hen day production two and six weeks after injection. The $\mathrm{P}_{1}$ group was able to reach its peak production (82.9\%) at week 29 , while the $\mathrm{P}_{2}$ group reached its peak at week 26 (78.9\%). In addition, it was found that the $\mathrm{P}_{2}$ group produced a soft-shelled egg and double egg yolk. Progesterone injection led to no significant effect on the egg weight, shape index, fertility, embryo viability, hatchability, and chick weight at hatch. The luteinizing hormone concentration was higher in $\mathrm{P}_{2}(1.52 \mathrm{ng} / \mathrm{ml})$, compared to $\mathrm{P}_{0}(1.36 \mathrm{ng} / \mathrm{ml})$ and $\mathrm{P}_{1}(1.34 \mathrm{ng} / \mathrm{ml})$ groups. It was concluded that progesterone hormone injection during the production phase of Arabic Gold chicken had a significant effect on egg production and caused varying egg production peak and luteinizing hormone concentration.
\end{abstract}

Keywords: Arabic Gold chicken, Egg quality, Hen day production, Luteinizing hormone, Progesterone

\section{INTRODUCTION}

Arabic gold chicken (Gallus turcicus) is a chicken breed widely reared in Indonesia for egg production. The breed is preferred by the local farmers due to its better Feed Conversion Ratio (FCR), which is around 3 to 4 (Rizal et al., 2015), compared to the native Kampung chicken for which the ratio is 6.73 on average (Pagala et al., 2019). The Arabic Gold hens begin to lay eggs by the age of five months and its peak production would be achieved at the age of 8-9 months (Indra et al., 2013). Some factors that have been known to determine egg production of laying hens include the genetic characteristics, age, nutrition intake, and rearing system (Sarica et al., 2012). Pirsaraei et al. (2008) added that hormonal status also plays a significant role in egg production.
Egg production is a complex process that involves hormonal interaction within chickens. Reproductive hormones, such as progesterone, play an important role in reproductional functions in fowls (Scanes, 2015; Han et al., 2017), including the development of reproductive organs, ovulation, albumen synthesis, eggshell's formation, and egg oviposition (Mishra et al., 2019). The progesterone hormone is one of the important steroid hormones that affects cattle and fowl (turkeys and laying egg hens) reproduction (Scanes, 2015). The progesterone hormone has been acknowledged to have a positive correlation with egg production. The progesterone hormone would promote the pre-ovulation release of luteinizing hormone (LH) that impacts egg production (Zaghari et al., 2009).

A previous study indicated that the secretion of progesterone hormone correlates with egg production on 
Guinea Fowl by providing an exogenous progesterone hormone to the feed and drinking water (Adeyinka et al., 2007). Aside from feed and drinking water, the exogenous progesterone can also be given by injection. Zaghari et al. (2009) conducted a study on the effect of progesterone injection on broiler chickens. In a study performed by Ito et al. (2011), it was found that progesterone hormone injection 20 hours before ovulation affects the release of sperm storage tubules in the ureterovaginal junction.

Although effort has been made to increase egg production (Samadi et al., 2020), there is still no report on the enhancement of egg production in Arabic Gold chicken regarding hormone application. Therefore, this study aimed to analyze the effect of progesterone hormone injection on Arabic gold chicken during the production phase towards the performance of egg production, fertility, and LH hormone profile.

\section{MATERIALS AND METHODS}

\section{Ethical approval}

This study has been approved by the Animal Ethics Committee of Universitas Brawijaya with number 001KEP-UB-2020 and has been declared to have fulfilled the ethical feasibility of the research. All procedures and care for chickens were in accordance with institutional guidelines for the use of animals in the study.

\section{Experimental design}

The study was conducted as experimental research using a completely randomized design in the poultry installation unit of the Politeknik Pembangunan Pertanian Malang, Indonesia, from August to December 2019. A total of 60 Arabic Gold chickens were divided into three treatment groups with 10 replications each and 2 chickens for each replication. The current study had three roosters at approximately 12 months of age to produce semen for the artificial insemination process twice a week. The data of this study were collected from a week of first chicken insemination or at the age of 26 weeks old.

\section{Research sample}

The Arabic Gold chickens used in the current study were obtained from "Mitra Ternak Juara Group" farm in Probolinggo, Indonesia, and has been vaccinated with Marek's Disease, Infectious Bursal Disease (IBD), Infectious Bronchitis (IB), Infectious Laryngo Tracheitis (ILT), and Newcastle Disease (ND) from the age of 1 day to 4 months. The chickens were firstly reared from the age of 16 weeks for battery cage and feed adaptation by using commercial laying hens feed containing $14-16 \%$ protein, $5-7 \%$ crude fiber, $4-7 \%$ crude fat, $5-7 \%$ ash, and 2500 $2700 \mathrm{Kcal} / \mathrm{kg}$ metabolizable energy, given ad libitum along with the drink. The hens were inseminated at the age of 25 weeks until 33 weeks and kept in individual coops with 14 hours of light and 10 hours of dark system daily.

\section{Research treatments}

The research treatment of this study entailed the injection of different concentrations of progesterone hormone to the Arabic gold chickens. The progesterone hormone used for the present study was P0478-5G produced by Tokyo Chemical Industry (TCI) Co, Ltd. The progesterone hormone injection doses for experimental hens included $0 \%$ or no injection (control), $1 \mathrm{mg} /$ chicken $\left(\mathrm{P}_{1}\right)$, and $2 \mathrm{mg} /$ chicken $\left(\mathrm{P}_{2}\right)$. The solvent used in the current study was sesame oil $(0.5 \mathrm{ml}$ of oil/ chicken, Correa et al., 2005). The progesterone hormone injection was performed subcutaneously. The hormone was injected five hours prior to the estimated ovulation as calculated from the previous egg-laying time. The injections were administered twice a week for four consecutive weeks (on weeks 28 to 31). Eggs were collected from two weeks before the injection time until two weeks after the injection to observe the egg production performance. The eggs from hormone-injected hens were then hatched at the temperature of $37.5^{\circ} \mathrm{C}$ with a humidity level of $55-60 \%$ (Mohan et al., 2015).

\section{Hen day production}

The observed variables in the present study included hen day production (HDP), egg qualities, and LH profile. The HDP was measured by comparing the number of eggs produced in a day with the number of hens; the result was then multiplied by 100\% (Pirsaraei et al., 2008). The HDP values were calculated for weekly production.

\section{Egg qualities}

The observed egg quality parameters included weight, size (length and width), shape index, and eggshell quality. Egg weight was measured using an analytic scale. The shape index is the comparison of egg width and length diameters multiplied by 100\% (Duman et al., 2016). The width and length of the egg were measured using vernier calipers. The exterior egg quality was observed by checking its surface, whether smooth, rough, or soft. The egg fertility percentage is achieved by dividing the number of fertile eggs by the total amount of observed eggs, the result is then multiplied by $100 \%$. The egg fertility was measured by the candling method. The candling was performed on the seventh day of the hatching period. 
Furthermore, the egg candling was also performed on the fourteenth and eighteenth days of the hatching period to determine the embryo viability. The embryo viability is the percentage of the live embryo at 14 or 18 hatching days of fertile eggs multiplied by $100 \%$ (Reijrink et al., 2010). The hatchability is the percentage of hatched eggs of the embryo of fertile eggs multiplied by $100 \%$ (Indrawati et al., 2015).

\section{Luteinizing hormone profile}

The concentration of LH in the blood plasma of subjects was measured two hours before and after the injection, the result was analyzed using Enzyme-linked Immunosorbent Assay (ELISA).

\section{Statistical analysis}

The qualitative data were analyzed descriptively, while the quantitative data were analyzed using analysis of variance, and followed by Duncan's Multiple Range Test. P-value less than 0.05 was considered statistically significant $(\mathrm{P}<0.05)$. The results were expressed as the mean \pm standard deviation $(\mathrm{SD})$.

\section{RESULTS}

\section{Hen day production}

The Arabic Gold chickens began to lay eggs at the age of 20 weeks and the initial egg production was 5.2\%. The HDP of Arabic Gold chicken injected with different progesterone levels in this study is presented in Figure 1. Figure 1 demonstrates that egg production gradually decreases as the chickens matured indicating varying peak production time frames. The control group receiving no treatment $\left(\mathrm{P}_{0}\right)$ experienced a decrease in production and its peak was on week 27 with HDP at $75.7 \pm 22.6 \%$ when other groups did not receive any progesterone hormone injection. The $\mathrm{P}_{1}$ group reached its peak production on week 29 with $\mathrm{HDP}$ at $82.9 \pm 9.64 \%$ while the $\mathrm{P}_{2}$ group reached its peak production on week 26 with the HDP at $77.9 \pm 12.3 \%$. The HDP data during the progesterone hormone injection treatment until week 33 is presented in Table 1.

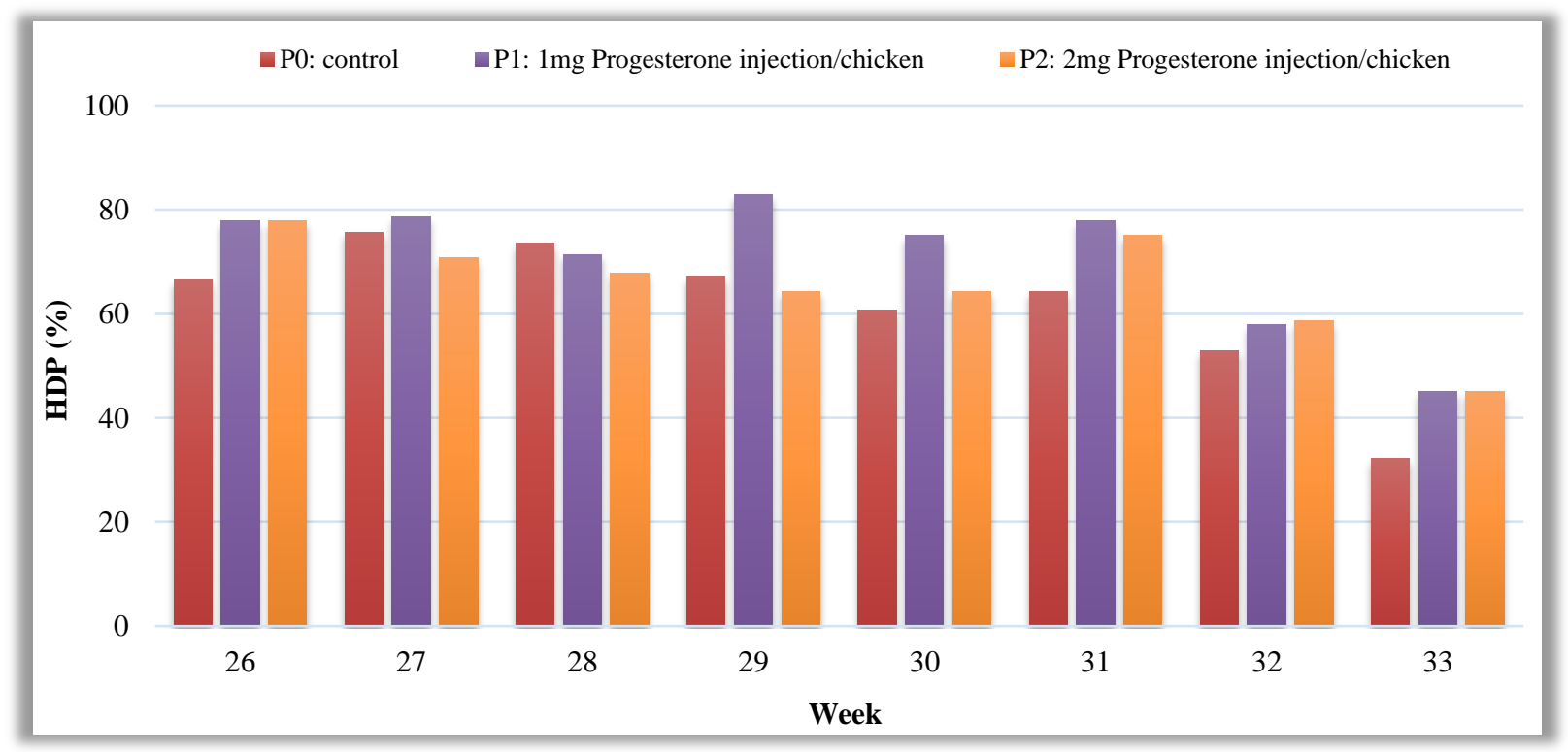

Figure 1. Hen day production of Arabic Gold chickens from week 26 until week 33 with different injected progesterone levels.

Table 1. Average hen day production of Arabic Gold chickens injected with different progesterone levels.

\begin{tabular}{|c|c|c|c|c|c|c|c|c|}
\hline Treatment $\operatorname{HDP}(\%)$ & 26 & 27 & 28 & 29 & 30 & 31 & 32 & 33 \\
\hline $\mathrm{P}_{0}$ & $66.4 \pm 25.4^{\mathrm{a}}$ & $75.7 \pm 22.6^{\mathrm{a}}$ & $73.6 \pm 14.7^{\mathrm{a}}$ & $67.1 \pm 19.4^{\mathrm{a}}$ & $60.71 \pm 23.6^{\mathrm{a}}$ & $64.3 \pm 11.7^{\mathrm{a}}$ & $52.9 \pm 11.8^{\mathrm{a}}$ & $32.1 \pm 13.6^{\mathrm{a}}$ \\
\hline $\mathrm{P}_{2}$ & $77.9 \pm 12.3^{\mathrm{a}}$ & $70.7 \pm 13.2^{\mathrm{a}}$ & $67.9 \pm 8.4^{\mathrm{a}}$ & $64.3 \pm 14.67^{\mathrm{a}}$ & $64.29 \pm 16.1^{\mathrm{a}}$ & $75.0 \pm 13.6^{\mathrm{a}}$ & $58.6 \pm 11.6^{\mathrm{a}}$ & $45.0 \pm 10.7^{\mathrm{b}}$ \\
\hline SEM & 3.81 & 2.30 & 1.67 & 5.77 & 4.29 & 4.13 & 1.80 & 4.29 \\
\hline
\end{tabular}

Different superscripts on each column indicate significant differences $(\mathrm{P}<0.05)$. The progesterone hormone was injected at $1 \mathrm{mg} /$ chicken for $\mathrm{P}_{1}$ and 2 $\mathrm{mg} /$ chicken for $\mathrm{P}_{2}$ from week-28 to 31 . 


\section{Egg qualities}

The egg quality parameters observed in the current study included egg weight, size (width and length), shape index (\%), and the eggshell. The exterior egg quality measurement in the present study is presented in Table 2, while the eggshell quality is indicated in Table 3.

Egg fertility and hatchability are two essential parameters in egg reproduction to produce the day-old chick. The egg fertility percentage was measured by conducting the candling test on the seventh day of the incubator. Table 4 indicates the ANOVA test of fertility among treatments. The obtained results revealed no significant difference between the treatment groups and the control group $(\mathrm{P}>0.05)$. The embryo viability during the hatchery period was observed through the candling test. In the present study, the embryo observed on day 14 and day 18 based on grouping indicated that the death occurred in the mid-phase. The embryo viability showed the number of living ones from the fertile eggs that fit the hatchery stage. The results of this study showed that the embryo viability due to hormone injection was not different $(\mathrm{P}>0.05)$ among all treatments. Therefore, it could be concluded that the progesterone hormone injection did not affect the chicken embryo viability which was supported by a relatively high result of all groups. The hatchability found in this study did not significantly differ among treatment groups $(\mathrm{P}>0.05)$, the hatched eggs were derived from layer hens with similar age (28 to 32 weeks).

\section{Luteneizing hormone profile}

Progesterone stimulates the LH hormone release prior to ovulation. The ELISA analysis results on the LH hormone concentration in the current study are presented in Figure 2, and the results of ANOVA analysis of LH concentrations are presented in Table 5. Figure 2 presents the progesterone hormone injection five hours before the ovulation could stimulate the LH hormone release. The ANOVA analysis (Table 5) indicated that the LH concentration was not significantly different $(\mathrm{P}>0.05)$ among treatment groups although $\mathrm{P}_{2}$ had a higher $\mathrm{LH}$ concentration than other treatments. A high dose of progesterone treatment could increase the LH concentration in the plasma to $1.52 \mathrm{ng} / \mathrm{ml}$ three hours before the predicted ovulation, or around 28 hours before the next oviposition.

Table 2. Exterior egg quality of Arabic Gold chickens injected with different progesterone levels.

\begin{tabular}{|c|c|c|c|c|c|}
\hline Treatment group & $\mathbf{P}_{0}$ & $\mathbf{P}_{1}$ & $\mathbf{P}_{2}$ & SEM & $P$-value \\
\hline Egg weight (g) & $38.9 \pm 1.58$ & $39.6 \pm 1.09$ & $39.7 \pm 1.06$ & 0.27 & $0.27^{\mathrm{ns}}$ \\
\hline Egg width $(\mathrm{cm})$ & $35.7 \pm 0.65$ & $36.1 \pm 0.67$ & $36.2 \pm 0.57$ & 0.15 & $0.18^{\mathrm{ns}}$ \\
\hline Egg length $(\mathrm{cm})$ & $46.4 \pm 1.16$ & $46.8 \pm 0.63$ & $46.4 \pm 0.54$ & 0.13 & $0.49^{\mathrm{ns}}$ \\
\hline Shape index $(\%)$ & $77.1 \pm 1.10$ & $77.3 \pm 3.62$ & $78.2 \pm 10.8$ & 0.34 & $0.19^{\mathrm{ns}}$ \\
\hline
\end{tabular}

ns: no significant difference between each treatment group $(\mathrm{P}>0.05)$

Table 3. Eggshell quality of Arabic Gold chickens injected with different progesterone levels.

\begin{tabular}{|c|c|c|c|c|}
\hline Parameter & Treatment group & $\mathbf{P}_{0}$ & $\mathbf{P}_{1}$ & $\mathbf{P}_{2}$ \\
\hline Smooth eggshell (\%) & & 93.2 & 88.1 & 87.7 \\
\hline Speckled smooth eggshell (\%) & & 4.44 & 5.03 & 8.10 \\
\hline Rough eggshell (\%) & & 2.37 & 6.85 & 4.25 \\
\hline Soft shell $(\%)$ & & 0 & 1.96 & 3.49 \\
\hline Double egg yolk & & 0 & 0 & 1.62 \\
\hline White colour (\%) & & 82.9 & 63.9 & 72.8 \\
\hline Brown colour $(\%)$ & & 17.1 & 36.1 & 27.2 \\
\hline
\end{tabular}


Table 4. Egg fertility evaluation of Arabic Gold chickens injected with different progesterone levels.

\begin{tabular}{|c|c|c|c|c|c|}
\hline $\begin{array}{ll}\text { Parameter } & \text { Treatment group } \\
\end{array}$ & $\begin{array}{c}\mathbf{P}_{\mathbf{0}} \\
\mathrm{N}=\mathbf{1 2 3}\end{array}$ & $\begin{array}{c}P_{1} \\
N=129\end{array}$ & $\begin{array}{c}P_{2} \\
N=121\end{array}$ & SEM & $P$-value \\
\hline Embryo viability to day $14(\%)$ & $97.2 \pm 5.91$ & $96.1 \pm 12.2$ & $97.4 \pm 4.16$ & 0.40 & $0.93^{\mathrm{ns}}$ \\
\hline Embryo viability to day $18(\%)$ & $94.9 \pm 8.86$ & $91.6 \pm 14.6$ & $94.1 \pm 6.07$ & 1.08 & $0.73^{\mathrm{ns}}$ \\
\hline DOC weight (g) & $25.9 \pm 1.05$ & $26.8 \pm 1.43$ & $26.8 \pm 0.95$ & 0.32 & $0.13^{\mathrm{ns}}$ \\
\hline
\end{tabular}

$\mathrm{N}$ : Number of hatched eggs, ns: No significant difference between each treatment group $(\mathrm{P}>0.05)$.

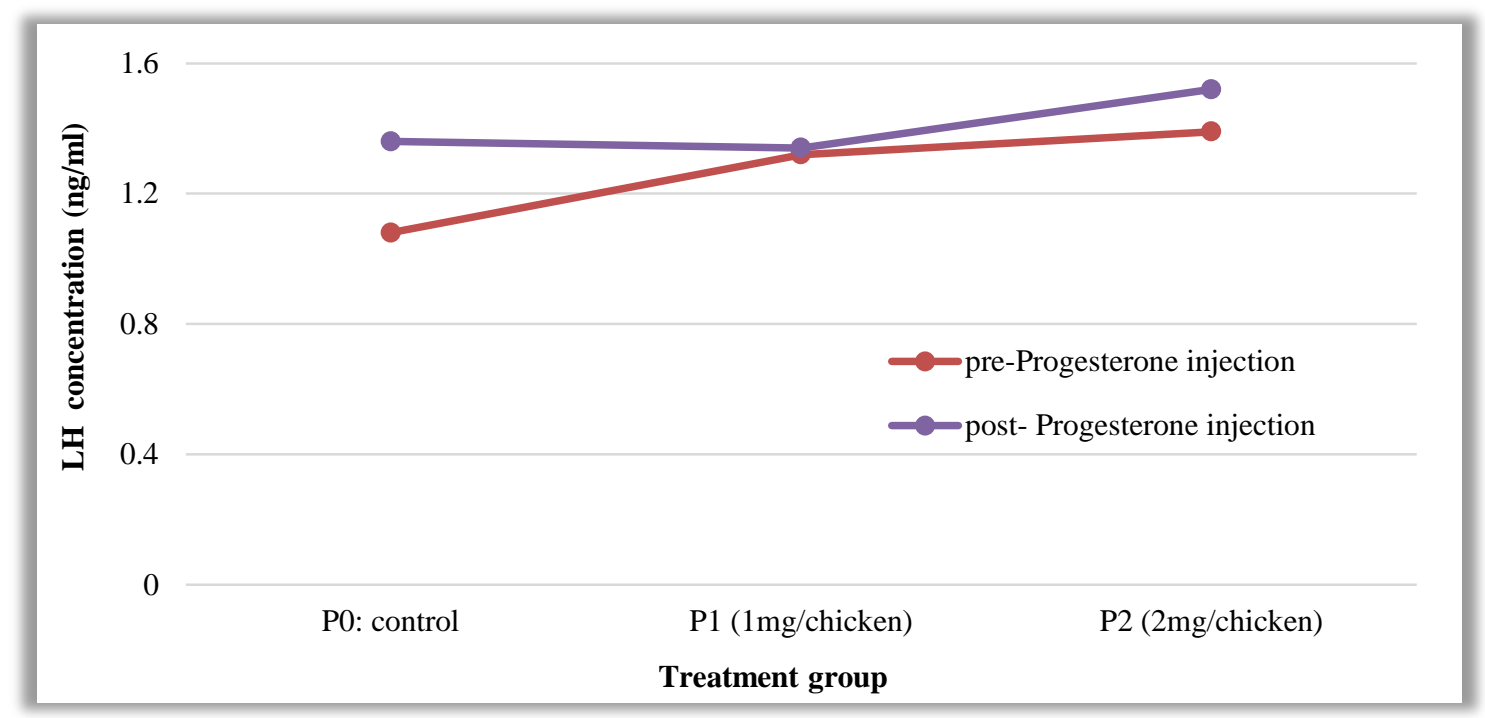

Figure 2. Luteinizing hormone concentration on each treatment group of Arabic Gold chickens from week 26 until week 33 with different injected progesterone levels.

Table 5. Luteinizing hormone concentration of Arabic Gold chickens injected with different progesterone levels.

\begin{tabular}{lcccc}
\hline Treatment & $\mathbf{P}_{\mathbf{0}}$ & $\mathbf{P}_{\mathbf{1}}$ & $\mathbf{P}_{\mathbf{2}}$ & $\boldsymbol{P}_{\text {-value }}$ \\
\hline Pre-progesterone injection & $1.08 \pm 0.21$ & $1.32 \pm 0.61$ & $1.39 \pm 0.52$ & $0.32^{\text {ns }}$ \\
Post-progesterone injection & $1.36 \pm 0.35$ & $1.34 \pm 0.44$ & $1.52 \pm 0.36$ & $0.52^{\mathrm{ns}}$ \\
\hline
\end{tabular}

ns: No significant difference between each treatment group $(\mathrm{P}>0.05)$.

\section{DISCUSSION}

The performance of egg production can be analyzed from the number of eggs produced by each chicken (Javed et al., 2003). The production parameter is achieved from the number of daily egg production, which is then converted to HDP, after that, the HDP collection is calculated to determine the weekly average. The HDP provides essential information to realize the daily egg production (Farooq et al., 2002; Pirsaraei et al., 2008).

The Progesterone hormone injection was administered during the production phase (28-31 weeks), the egg production data was collected from two weeks before the treatment (week-36) until the egg production reached the percentage of $74.2 \%$. Production data was calculated for 8 weeks started from week 26 until 33 (2 
weeks before the treatment, 4 weeks during the treatment, and 2 weeks after the treatment).

Table 1 indicates that progesterone hormone injection affects egg production $(\mathrm{P}<0.05)$ in week two of the treatment process (week-29) and two weeks after the treatment (week 33). The present study applied a low-dose progesterone hormone injection (1 $\mathrm{mg} /$ chicken), which could improve egg production only until week 29 or similar to the second week of the treatment, followed by a decrease in egg production. The low-dose progesterone treatment is proven to achieve the highest production compared to the control group. Moreover, the high dose of progesterone injection $(2 \mathrm{mg} / \mathrm{chicken})$ represented that the egg production dropped for three weeks after the initiation of treatment, but started to increase again from the last week of the treatment (week 31) before the egg production decreased again. This finding was in line with a study by Zaghari et al. (2009) that indicated that progesterone injection could significantly affect egg production.

The chicken that gets progesterone injection produces fewer stable eggs than those who receive no treatment. A similar finding by the current study presented that after the progesterone injection was administered, egg production of turkeys (Bacon and Liu, 2004), broilers (Liu and Bacon, 2005), and Japanese quail (Liu and Bacon, 2004) decreased. On the last observation of week 33, all groups experienced a decrease in egg production, but treatment groups had a higher decrease (45\%), compared to the control group (32\%).

The characteristics of egg quality depend on several factors, namely the age and genus of the chicken, the nutrient of the feed, and chicken weight (Sarica et al., 2012). Besides, other factors that affect egg production include the maintenance system, the oviposition time, molting induction, general stress, heat stress, diseases, addition of an exclusive product to the feed, and the hormonal status of the chicken (Pirsaraei et al., 2008; Ahmadi and Rahimi, 2011). A stressful situation and other physiological conditions can generally affect oviposition, which eventually affects egg quality (Ahmadi and Rahimi, 2011). The treatment of progesterone hormone injection in this study for four weeks during the egg production had no significant effect on the exterior egg quality $(\mathrm{P}>0.05)$ due to the similar treatment on feed, maintenance method, and careful treatments provided to all chicken to avoid stress.

Factors that affect the egg weight are the chicken age, strain and breed, feed nutrients, chicken weight, egglaying time, environmental temperature, and diseases (Bell and Weaver, 2002). The egg weight of Arabic Gold chicken breed in the present study was in the normal range. The range was in agreement with a study conducted by Bakar et al. (2005), which indicated that the weight of Arabic chicken breed could range from around 31 to 52 grams per egg. Table 3 presents that the three treatments of the Arabic chicken breed do not differ significantly regarding the egg weight $(\mathrm{P}>0.05)$. The result of the study was lower in value than the results from a study conducted by Yumna et al. (2011) in which the weight of eggs was $46.81 \pm 2.22$ grams during the age of 32 to 36 weeks. This difference could be due to the age difference of the subjects used in these two studies. The progesterone hormone affects the eggshell formation in the reproductive tract (Zhang et al., 2019) which is assumed to affect the egg weight; nevertheless, the finding showed different results. This means that the hormone injection does not have any impact on the egg weight.

Egg shape index (SI) is the width and length ratio of an egg, it is an essential criterion in determining the quality of an egg. An egg that does not have a standard shape, such as misshapen, too round, or a flat surface on one side, is not included in grade AA (almost perfect) or grade A (slightly under AA) since it does not comply with the standard oval egg shape (Duman et al., 2016). The shape index correlates with the egg shape. The variation of the egg index is between 0.65-0.82 (Yuwanta, 2010). The higher the egg shape index (0.82), the more round the egg shape. On the contrary, the lower the egg shape index, the more oval and tapering the egg. Yuwanta (2010) also explains that the egg shape index will progressively decrease as laying time increases; right after the egg is laid, the egg shape index ranges around 0.77 , but at the end of laying time, the index is around 0.74 . The current study used eggs derived from chickens during the midproduction time, eventually, their shape index was about $77-78 \%$.

The variable of eggshell quality underwent a descriptive analysis. On treatment $\mathrm{P}_{2}$, there was a double egg yolk occurrence with a percentage of $1.62 \%$. The double egg yolk occurred due to the progesterone hormone injection that stimulated the LH hormone release before the ovulation which resulted in the occurrence of double ovulation from the mature follicle. After the double egg yolk started the hatching stage, on day seven, it is found infertile as a result of the candling test. This finding was in line with Buchanan et al. (2002) who reported two or more follicles on each position of the hierarchy that could produce two or more follicles in a day, an egg with multiple ovulation cannot be suitable to undergo the incubation. 
Several studies have indicated that progesterone correlated with eggshell quality. The Progesterone hormone affects the ovary and hypothalamus leading to stimulating the surge of LH used for the ovulation process. The progesterone injection can have an impact on the quality of the eggshell during the calcification initiation (Zhang et al., 2019). The findings of the current study indicated that the progesterone hormone injection resulted in the soft-shell egg whose percentage was higher for the high-dose treatment $\mathrm{P}_{2}(4.25 \%)$, compared to the $\mathrm{P}_{1}$ treatment that reached $1.96 \%$. The soft eggshell occurrence was similar to a study performed by Zaghari et al. (2009) concluding that progesterone injection caused an increase in eggshell qualities with a softshell during the first week of the hormone injection initiation. The double egg yolk and soft shell are considered to increase ovulation although these eggs are not suitable for hatching and not to be counted as good eggs (Zaghari et al., 2009). Liu and Bacon (2005) also observed a higher occurrence of the softshell eggs after the injection of progesterone in the broiler chicken farm.

The shell color is one of the parameters of eggshell quality (Liu et al., 2010). Eggshell color is a result of a stack of pigment during the egg formation process in the oviduct. The type of pigment depends significantly on breed type and its genetic characteristics (Liu and Cheng, 2010). The Arabic chicken breed is known to produce eggs with white to the light brown shell which resembles the eggs of free-range chicken (Yumna et al., 2011). In the present study, the color of the shell was still within the normal range. The shell color depends on the pigment produced by shell glad during the shell formation. The color of the egg can be determined when it is inside the uterus and the end of the oviduct. During the shell formation, the epithelial cells on the surface of the shell glands (uterus) start to synthesis the color pigments (Baylan et al., 2017).

Egg fertility and hatchability are two of the essential parameters in egg reproduction to produce the day-old chick (King'ori, 2011). These parameters depend on genetic and environmental factors. Both egg fertility and hatchability measurement in the current study was estimated 83-89\%. King'ori (2011), explained the factors affecting fertility and hatchability included nutrient, chicken in the flock, egg factors, hatchery (natural and artificial incubation), and environmental factors.

The spermatozoa are inseminated to the cloaca, and consequently stored for several days in the sperm storage tubule (SST) located between the uterovaginal junction (UVJ) and infundibulum. The site has a receptor for progesterone and estrogen (Yoshimura et al., 2000) that is shown to determine the fertility rate. The correlation between the progesterone hormone and egg fertility was supported by the finding of Ito et al. (2011) that reported progesterone as one of the factors causing the spermatozoa release towards the fertilization site, which could be active for 20 hours after the oviposition. The highest egg fertility of Arabic gold chickens in this study was found at $2 \mathrm{mg}$ progesterone hormone injection ( $\mathrm{P}_{2}$ treatment) which was at $88.1 \pm 10.8 \%$. This finding was higher compared to the finding by Astomo et al. (2016), showing that the egg fertility of the Arabic chicken breed was around 62.5$79.2 \%$.

Hatchery process, the death of embryo detected through the candling test and is classified into three phases, including the death of the initial embryo on day 10 (5 to 10 days), death of the embryo in the middle phase, observed on day 18, and death in the final phase of hatchery process which means day 21 , and the embryo would not hatch (Larivière et al., 2009). This study observed the embryo death on days 14 and 18indicating that the death occurred in the mid-phase. The embryo viability indicated the number of living ones from the fertile eggs that fit the hatchery stage. The results showed that the progesterone hormone injection did not give significant differences $(\mathrm{P}>0.05)$ on embryo viability between all treatments Therefore, it can be concluded that the progesterone hormone injection did not affect the chicken embryo viability proven by a relatively high result of all treatment groups.

The hatchability is a critical factor of hatching in the breeding farm, it depends on many factors, such as hens in the flocks, egg fertility, and egg handling (Liu and Ngadi, 2012). There was no significant difference among treatment groups in terms of hatchability $(\mathrm{P}>0.05)$ for the hatched eggs derived from layers aged 28-22 weeks. The obtained result was higher in value, compared to a study conducted by Astomo et al. (2016) that reported the hatchability of the Arabic chicken breed for natural breeding to get the highest percentage of $76.7 \%$. It was also stated that the affecting factors included egg quality, nutrition of hens, duration of egg storing, cage quality (temperature and humidity), and the hens quality as the egg producer. In the current study, the layer hens were selected according to specific parameters, qualified feed, good egg quality, the eggs were stored at $18^{\circ} \mathrm{C}$ temperature before entering the incubation machine, therefore, the hatchability rate was relatively high.

The hatching weight of Arabic chicken breed due to progesterone hormone injection in this study did not 
significantly differ among treatment groups $(\mathrm{P}>0.05)$. The result from hatching weight in this study reported a relatively lower one than a study performed by Astomo et al. (2016) that stated the hatching weight of Arabic chicken breed ranges around $29.4 \mathrm{~g}$, and was significantly affected by initial egg weight before entering the incubation machine. A bigger egg has more nutrition than a smaller one. The embryo that is lacking nutrients would not grow properly and affect the hatched chicks. The current study indicated that the progesterone hormone injection did not have any significant effect $(\mathrm{P}>0.05)$ on the egg weight, it does not have a substantial impact on the hatching weight. The hatched weight of this study was lower than the one performed by Rohmad and Fitri (2016) that presented the hatched weight range of Arabic chicken breed as $31.2-32.53 \mathrm{~g}$ and this difference was due to the egg weight and different age of layer hens.

A high-dose of progesterone injection could increase the LH concentration in the plasma up to $1.52 \mathrm{ng} / \mathrm{ml}$ at three hours before the time that predicted ovulation, or around 28 hours prior to the next oviposition. This finding was in accordance with a study by Bronneberg et al. (2007) that the plasma LH concentration increases by $1-2$ $\mathrm{ng} / \mathrm{ml}$ and starts from 11 hours before the oviposition. The obtained results of a study by Lewis et al. (2005) also reported that the LH concentration in chicken was within the range of 1.1-1.2 $\mathrm{ng} / \mathrm{ml}$ during different photoperiods.

The increase of $\mathrm{LH}$ concentration in $\mathrm{P}_{2}$ was still within normal levels despite the multiple ovulation caused by the double egg yolk. The high $\mathrm{LH}$ in $\mathrm{P}_{2}$ treatment was then expected as the cause of double-yolked egg, as both factors known to be correlated (Bédécarrats et al., 2016). Another research found that multiple ovulation occurs due to the defect in the follicle hierarchy than the distraction on the LH concentration profile (Buchanan et al., 2002).

\section{CONCLUSION}

The progesterone hormone injection in Arabic gold chicken during the production phase (28-31 weeks) had a significant effect on egg production two and six weeks after the injection. The progesterone hormone injection caused a varying production peak, and reduce the overall egg production. The progesterone hormone injection did not significantly affect the egg weight, shape index, fertility, embryo viability, hatchability, and hatched weight. Nevertheless, a high-dose of progesterone injection (2 $\mathrm{mg} / \mathrm{chicken})$ increased the occurrence of softshell and double egg yolk, as well as LH concentration in plasma blood.

\section{DECLARATIONS}

\section{Competing interests} interests.

The authors declare that there are no competing

\section{Author's contributions}

Iswati and Muhammad Halim Natsir designed the research. Iswati and Muhammad Halim Natsir performed the research and analyzed the data. Iswati wrote the manuscript. Gatot Ciptadi, Muhammad Halim Natsir, and Trinil Susilawati participated in the revision of the manuscript. All authors have read and approved the final version of the manuscript.

\section{Acknowledgments}

Sincere gratitude is addressed to the Chief of the Agricultural Human Resource Extension and Development Agency of the Ministry of Agriculture as the scholarship provider, the Director of Agricultural Development Polytechnic of Malang that has granted permission to access the research facility.

\section{REFERENCES}

Adeyinka FD, Eduvie LO, Adeyinka IA, Jokthan GE, and Orunmuyi M (2007). Effect of progesterone secretion on egg production in the grey helmet guinea fowl (Numida meleagris galleata). Pakistan Journal of Biological Sciences, 10(6): 998. DOI: https://www.doi.org/10.3923/pjbs.2007.998.1000

Ahmadi F, and Rahimi F (2011). Factors affecting quality and quantity of egg production in laying hens: A review. World Applied Sciences $\begin{array}{lll}\text { Journal, } & \text { 12(3): } & \text { 372-384. }\end{array}$ https://www.dos.org/wasj/wasj12(3)/21.pdf

Astomo W, Septinova D, and Kurtini T (2016). The effect of sex ratio Arabic chicken on fertility, hatchability, and doc weight. Jurnal Ilmiah Peternakan Terpadu, 4(1): 6-12. DOI: https://www.doi.org/10.23960/jipt.v4i1.p\%25p

Bacon WL, and Liu HK (2004). Progesterone injection and egg production in Turkey hens. Biology of Reproduction, 71: 878-886. DOI: https://www.doi.org/10.1095/biolreprod.104.027672

Bakar A, Pambudi GT, and Sunarto (2005). Performance of free-range chicken and biosecurity in breeding centers for superior dualpurpose cattle and chickens. Proceedings of the National Workshop on Local Chicken Development Technology Innovation, pp. 61-85. Available http://perpustakaan.pertanian.go.id/repository litbang/repository/art ikel/0/0/2005/0/5900

Baylan M, Celik LB, Akpinar GC, Alasahan S, Kucukgul A, and Dogan SC (2017). Influence of eggshell colour on egg yolk antibody level, incubation results, and growth in broiler breeders. Revista Brasileira de Zootecnia, 46(2): 105-112. DOI: https://www.doi.org/10.1590/s1806-92902017000200004

Bédécarrats GY, Baxter M, and Sparling B (2016). An updated model to describe the neuroendocrine control of reproduction in chickens. General and Comparative Endocrinology, 227: 58-63. DOI: https://www.doi.org/10.1016/j.ygcen.2015.09.023

Bell DD, and Weaver WD (2002). Commercial chicken meat and egg production, $5^{\text {th }}$ Edition. Springer Science and Business Media Incorporation, pp. 187-198. Available at: 
https://www.worldcat.org/title/commercial-chicken-meat-and-eggproduction/oclc/840283525

Bronneberg RGG, Taverne MAM, Dieleman SJ, Decuypere E, Bruggeman V, Vernooij JCM, and Stegeman JA (2007). The relation between ultrasonographic observations in the oviduct and plasma progesterone, luteinizing hormone and estradiol during the egg laying cycle in ostriches. Domestic Animal Endocrinology, 32(1): 15-28. DOI: https://www.doi.org/10.1016/j.domaniend.2005.12.006

Buchanan S, Robertson GW, and Hocking PM (2002). Comparative changes in plasma concentrations of progesterone, oestradiol and LH during the ovulatory cycle in a multiple ovulating male line and a single ovulating traditional line of turkeys. Reproduction, 123(1): 127-133. DOI: https://www.doi.org/10.1530/rep.0.1230127

Correa SM, Adkins-Regan E, and Johnson PA (2005). High progesterone during avian meiosis biases sex ratios toward females. Biology $\begin{array}{llll}\text { Letters, } & 1(2): & 215-218 . & \text { DOI: }\end{array}$ https://www.doi.org/10.1098/rsbl.2004.0283

Duman M, Şekeroğlu A, Yıldırım A, Eleroğlu H, and Camci O (2016). Relation between egg shape index and egg quality characteristics. European Poultry Science, 80: 1-9. DOI: https://www.doi.org/10.1399/eps.2016.117

Farooq M, Mian MA, Durrani FR, and Syed M (2002). Egg production performance of commercial laying hens in Chakwal district, Pakistan. Livestock Research for Rural Development, 14(2): Article \#15 Available at: https://www.cipav.org.co/lrrd//rrd14/2/faro142.htm

Han S, Wang Y, Liu L, Li D, Liu Z, and Shen X (2017). Influence of three lighting regimes during ten weeks growth phase on laying performance, plasma levels- and tissue-specific gene expression of reproductive hormones in Pengxian yellow pullets. PLOS ONE, 12(5): 1-11. DOI: https://www.doi.org/10.1371/journal.pone.0177358

Indra G, Achmanu A, and Nurgiartiningsih A (2013). Production performance of Arabic chickens (Gallus turcicus) based on feather color. Journal of Tropical Animal Production, 14(1): 8-14. Available

https://ternaktropika.ub.ac.id/index.php/tropika/article/view/187

Indrawati E, Saili T, Rahadi S, and Nafiu LO (2015). Fertilitas, daya hidup embrio, daya tetas dan bobot tetas telur ayam ras hasil inseminasi buatan dengan ayam Tolaki. Journal of Chemical Information and Modeling, 53(9): 1689-1699. DOI: https://www.doi.org/10.33772/jitro.v2i2.3796

Ito T, Yoshizaki N, Tokumoto T, Ono H, Yoshimura T, Tsukada A, Kansaku N, and Sasanami T (2011). Progesterone is a spermreleasing factor from the sperm-storage tubules in birds. $\begin{array}{llll}\text { Endocrinology, } & 152(10): & 3952-3962 . & \text { DOI: }\end{array}$ https://www.doi.org/10.1210/en.2011-0237

Javed K, Farooq M, Mian MA, Durrani FR, and Mussawar S (2003). Flock size and egg production performance of backyard chicken reared by rural woman in Peshawar, Pakistan. Livestock Research for Rural Development, 15(11): Article \#80. Available at: https://www.lrrd.cipav.org.co/lrrd15/11/jave1511.htm

King'ori AM (2011). Review of the factors that influence egg fertility and hatchabilty in poultry. International Journal of Poultry Science, 10(6): 483-492. DOI: http://www.doi.org/10.3923/ijps.2011.483.492

Larivière J, Michaux C, and Leroy P (2009). Genetic parameters of embryonic viability traits in a traditional chicken breed genetic parameters of embryonic viability traits in a traditional chicken breed. International Journal of Poultry Science, 8(12): 1183-1188. DOI: https://www.doi.org/10.3923/ijps.2009.1183.1188

Lewis PD, Ciacciariello M, Ciccone NA, Sharp PJ, and Gous RM (2005). Lighting regimens and plasma LH and FSH in broiler breeders. British Poultry Science, 46(3): 349-353. DOI: https://www.doi.org/10.1080/00071660500098509
Liu H, and Bacon WL (2004). Effect of chronic progesterone injection on egg production in Japanese Quail. Poultry Science, 83: 2051-2058. DOI: https://www.doi.org/10.1093/ps/83.12.2051

Liu H, and Bacon WL (2005). Changes in egg production rate induced by progesterone injection in broiler breeder hens. Poultry Science, 84: 321-327. DOI: https://www.doi.org/10.1093/ps/84.2.321

Liu HC, and Cheng TWK (2010). Eggshell Pigmentation: A Review. Journal of the Chinese Society of Animal Science, 39(2): 75-89. Available https://www.cabdirect.org/cabdirect/abstract/20123082670

Liu HC, Hsiao MC, Hu YH, Lee SR, and Cheng WTK (2010). Study in Blue-shelled and White-shelled Ducks. Asian-Australasian Journal of Animal Sciences, 23(2): 162-168. Available at: https://www.ajas.info/upload/pdf/23-22.pdf

Liu L, and Ngadi MO (2012). Detecting fertility and early embryo development of chicken eggs using detecting fertility and early embryo development of chicken eggs using near-infrared hyperspectral imaging. Food Bioprocess Technol, 6: 2503-2513. DOI: https://www.doi.org/10.1007/s11947-012-0933-3

Mishra B, Sah N, and Wasti S (2019). Genetic and hormonal regulation of egg formation in the oviduct of laying hens, In: PoultryAdvanced Learning. IntechOpen, London, Pp. 1-10. DOI: https://www.doi.org/10.5772/intechopen.85011

Mohan J, Sharma SK, Kolluri G, Tyagi JS, and Kataria JM (2015). Selection of diluent for short term preservation of guinea fowl semen. Asian Journal of Animal and Veterinary Advances, 10(8): 360-364. DOI: https://www.doi.org/10.3923/ajava.2015.360.364

Pagala MA, Hafid H, Sandiah N, Aku AS, Zulkarnaen D, Has H, Badaruddin R, and Kurniawan W (2019). Feeding substitution using fish waste, papaya leaf and banana peel for Kampung chicken production. International Journal of Poultry Science, 18(10): 499503. DOI: https://dx.doi.org/10.3923/ijps.2019.499.503

Pirsaraei ZA, Shahneh AZ, Zaghari M, Zamiri MJ, and Mianji GR (2008). Effect of testosterone and growth hormone injection before puberty on follicles size, rate of egg production and egg characteristics of the Mazandaran Native breeder hens. African

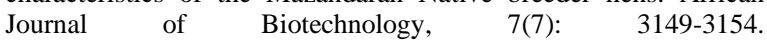
https://www.doi.org/10.5897/AJB08.431

Reijrink IAM, van-Duijvendijk LAG, Meijerhof R, Kemp B, and vanden-Brand H (2010). Influence of air composition during egg storage on egg characteristics, embryonic development, hatchability, and chick quality. Poultry Science, 89(9): 1992-2000. DOI: https://doi.org/10.3382/ps.2009-00610

Rizal Y, Nuraini, Mirnawati, Mahata ME, Darman R, and Kurniawan D (2015). Production performance of Gold Arab laying-hens fed diet containing Neurospora crassa fermented palm kernel cake. International Journal of Poultry Science, 14(12): 6238-632. DOI: https://www.doi.org/10.3923/ijps.2015.628.632

Rohmad, and Fitri S (2016). The effect of screening frequency and washing with disinfectant solution on hatchability, mortality and egg weight Arabic Chicken. Jurnal Fillia Cendekia, 1(1): 50-57. Available at: https://fp.uniska-kediri.ac.id/ejournal

Samadi, Wajizah, and Khairi F (2020). Feed formulation for laying hens and feed additive production based on local resources in Aceh $\begin{array}{llll}\text { Besar District, } & 2(1): & 25-32 . & \text { DOI: }\end{array}$ https://www.doi.org/10.24198/mktt.v2i1.25475

Sarica M, Onder H, and Yamak US (2012). Determining the most effective variables for egg quality traits of five hen genotypes. International Journal of Agriculture and Biology, 14(2): 235-240. Available Avallable 列 $\mathrm{yID}=56$

Scanes CG (2015). Sturkie's Avian Physiology, $6^{\text {th }}$ Edition. SpringerVerlag, New York, pp. 503-504. Available at: 
https://www.elsevier.com/books/sturkies-avianphysiology/scanes/978-0-12-407160-5

Yoshimura Y, Koike K, and Okamoto T (2000). Immunolocalization of progesterone and estrogen receptors in the sperm storage tubules of laying and diethylstilbestrol-injected immature hens. Poultry Science, 79: 94-98. DOI: https://www.doi.org/10.1093/ps/79.1.94

Yumna MH, Zakaria A, and Nurgiartiningsih VMA (2011). Kuantitas dan kualitas telur ayam arab (Gallus turcicus) silver dan gold. Jurnal Ilmu-Ilmu Peternakan, 23(2): 19-24. Available at: https://jiip.ub.ac.id/index.php/jiip/article/view/138

Yuwanta T (2010). Telur dan kualitas telur, $1^{\text {st }}$ Edition. UGM Press, Yogyakarta,
$50-51$. https://ugmpress.ugm.ac.id/id/product/peternakan/telur-dankualitas-telur

Zaghari M, Taherkhani R, and Honarbakhsh S (2009). Effects of progesterone injection on performance, plasma hormones and ovarian morphology of ad libitum and restricted fed broiler breeder hens. African Journal of Biotechnology, 8(22): 6481-6489. DOI: https://www.doi.org/10.5897/AJB09.1381

Zhang J, Wang Y, Zhang M, Xiong SA, Rajput, Liu Y, and Desheng Q (2019). The differences of gonadal hormones and uterine transcriptome during shell calcification of hens laying hard or weak-shelled eggs. BMC Genomics, 20(1): 1-12. DOI: https://www.doi.org/10.1186/s12864-019-6017-2 